\title{
Confessions of a Grumpy Old Man
}

\author{
Erik Brinch Petersen* \\ Department of Archaeology, Ethnology, History, Europe
}

Submission: January 22, 2019; Published: February 05, 2019

*Corresponding author: Erik Brinch Petersen, Department of Archaeology, Ethnology, Greek \& Latin, History, Europe

\section{Mini Review}

While reading this paper the old saying of "too many cooks spoil the broth" comes easily to one's mind. According to the title and to the abstract this paper deals with the many changes of the Baltic Sea during the Early and Mid-Holocene, and how different groups of Mesolithic people lived with different adaptations [1]. The Baltic Sea basin constitutes the classic example of the substantial changes after the last Glaciation like change of temperature, withdrawal of the Ice cap, the interplay of raising water and raising land creating either lake or sea stages according to who of the two were winning the race. Much weight is here put on the minor cold oscillations, the PBO, the 8.2 , the 6.3 , and the idea is, that they apparently had an influence on the Mesolithic people around the basin. That the short-lived cold oscillations had a grave impact on the local Mesolithic population has for long been popular in Southern Europe and the Near East and is now being applied to the Baltic Basin. Unfortunately, no information about how we see their shortlived effects on the Prehistoric people, but it is nice to know, that some of our colleagues do follow a southern trend.

Next comes a chapter on the settlements, and this is a very strange part, as only a tiny selection of sites spanning from a single Ahrensburg site, still undated, on the southern tip of Lolland, Denmark, overlooking a part of the Baltic Sea so rich in submarine sites though all a much later date, Kongemose and Ertebølle. The Scanian evidence to the caleidoscope are the two Maglemose sites, one submarine of Haväng and the recently excavated Norje Sunnansund from the Eastern coast of Scania. The Finnish project in Lake Saimaa, "Lost Inland Landscapes", at the Easternmost part of the Baltic Sea constitutes the Eastern example. The southern sites are the Maglemose ones from Northern Germany, Friesack 4 and 27a together with the ones from Duvensee. To me surprize, the Danish Maglemose sites make default, while some of the mentioned sites are known only from a preliminary stage of investigation, but perhaps this is the real motive behind the paper, trying to inform the rest of us ignorant about investigations still underway, or about papers still in press.
"Settlement strategy is quite well understood" it is claimed, and this comes certainly as a surprise. Unfortunately, there is no explanation for the mentioned settlement strategy, but as it is "well understood", there is, of course, no reason to go into details. Despite the main topic, the Baltic Sea and its Mesolithic population, much effort is finally used and wasted, on the hinterland. Of course, this ought to be an important issue, but unfortunately, we are simply told that "marine sites can be located several kilometres from the seashores". However, I know of no one from the area, so please enlighten me!

Remain some archaeological expressions à la mode. Central places, what are they? Now I know of only one candidate for this expression, and this will be the two sides of the river Motala (Antiquity). The next expression is persistent places, what are they? According to my understanding, it must be a site occupied continuously over several years or what? Sedentisme is also a hot topic within the Mesolithic, but despite some postulates we are still left with secondary evidence like complicated fishing installations or the presence of so-called cemeteries. Also, territoriality is an interesting research topic, but the known approaches are simply left out here, while no new ones have been attempted. Shame on you. Instead we hear about the frivolous sexual habits of the Evenks, Siberia, or how the Evenks drink melted snow, while the Mistassini Cree, boreal Canada, prefer the cold water from the river or lake, and what that has to do with adaptations around the Baltic Sea simply evades my understanding.

The conclusion, there is none, instead we must go through a concluding perspective. Here we are told that the aquatic resources were an important resource for the occupation of the hinterland. Also, that a multidisciplinary perspective and approach is de rigeur, and surprize, this is the single claim I can agree with, as did our archaeological Danish forefathers more than 160 years ago.

Finally, the present paper is a fine illustration of the system with anonymous peer reviews, or lack of the same. Has 
Quaternary Science Reviews given up the system? Certainly, the list of references can give a conscious reviewer headache, and what an overkill. Or is this long list of futile references the reason why the paper has been accepted by the editors in charge. This would certainly be in fine harmony with the paper itself, where real evidence is absent, and the claims are based on secondary evidence. - Never have so many scientific and founding agencies (list of acknowledgments) been so mislead (the paper), by so many scientists (list of authors), while reviewers make default (no names, and fortunately for their sake).

\section{References}

1. Gross D, Zander A, Boethius A, Dreibrodt S, Grøn O, et al. (2018) People, lakes and seashores: Studies from the Baltic Sea basin and adjacent areas in the early and Mid-Holocene. Quaternary Science Reviews 185(1): 27-40.

\section{Your next submission with Juniper Publishers will reach you the below assets}

- Quality Editorial service

- Swift Peer Review

- Reprints availability

- E-prints Service

- Manuscript Podcast for convenient understanding

- Global attainment for your research

- Manuscript accessibility in different formats

( Pdf, E-pub, Full Text, Audio)

- Unceasing customer service

Track the below URL for one-step submission https://juniperpublishers.com/online-submission.php 